\title{
Neurological research and practice: the first milestone has been reached
}

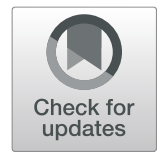

Werner Hacke

Almost 2 years ago, on February 28, 2019, the first set of articles appeared in the new peer-reviewed open access online-only scientific Journal "Neurological Research and Practice" (NRP). The journal is published jointly by Biomed Central (BMC, a division of Springer-Nature Publishers) and the German Neurological Society (Deutsche Gesellschaft für Neurologie, DGN, Berlin). NRP is the official journal of the German Neurological Society (Deutsche Gesellschaft für Neurologie (DGN)), one of the largest national neurological societies worldwide with more than 10,000 members. NRP was created by the leadership of the DGN as an international English language publication with a broad thematic scope reflecting all clinical, translational, and basic research aspects of neurology and neuroscience [1]. Currently the society bares all publication cost. There are no fees for authors.

In the first year, we published 41 articles. We were pleased by the quality of the reviews (12) and research articles (16), the innovation of the clinical trial protocols, and the reliability of Guidelines and Standard operating procedures [2]. This development continued in the second year of publications: Over 50 articles were published (Table 1). We noticed a sharp increase of letters, about half of the COVID-19 related, while the number of reviews and Research arti- cles remained stable. Overall, we had an acceptance rate of $50 \%$, with the number of letters rejected in the order of $70 \%$.

In total, more than 120 citations have been counted by now. Table 2 lists the five articles [3-7] with the highest citations ( 2 research articles, 2 reviews, and a letter published in 2020. It is important to note that clinical trial protocols, guidelines, and also SOPs are frequently cited. In our opinion, this underlines the importance of these article types. The far majority of the letters were published in 2020 and several have already been cited.

Access rates also show how much interest some of our articles have received. A review on the "resumption of oral anticoagulation after intracerebral hemorrhage" has already received almost 10,000 accesses [8]. Other highly accessed articles are found in Table 3 [9-11]. Three of them were published in 2020. The publication highlights include the first-ever guideline on "Neurological manifestations of COVID 19" [9], the results of a national registry of fiberoptic endoscopic evaluation of swallowing [3], the worldwide first documentation of the population-wide uptake of mechanical thrombectomy [4], and a review of antibody associated movement disorders [11].

In December 2020, NRP was included into Pubmed in a record-breaking time of less than 2 years after

(c) The Author(s). 2021 Open Access This article is licensed under a Creative Commons Attribution 4.0 International License, which permits use, sharing, adaptation, distribution and reproduction in any medium or format, as long as you give appropriate credit to the original author(s) and the source, provide a link to the Creative Commons licence, and indicate if changes were made. The images or other third party material in this article are included in the article's Creative Commons licence, unless indicated otherwise in a credit line to the material. If material is not included in the article's Creative Commons licence and your intended use is not permitted by statutory regulation or exceeds the permitted use, you will need to obtain permission directly from the copyright holder. To view a copy of this licence, visit http://creativecommons.org/licenses/by/4.0/. 
Table 1 Submissions, article types, and citations 2019 and 2020

\begin{tabular}{lllllllll}
\hline Year & Reviews & Research Articles & Clin. Trial Prot. & Guidelines & SOPs & Letters & Editorials & Total \\
\hline 2019 & 12 & 16 & 4 & 4 & 3 & 1 & 1 & 41 \\
2020 & 11 & 14 & 6 & 5 & 1 & 12 & 1 & 50 \\
Citations & 33 & 54 & 7 & 7 & 3 & 9 & 1 & 113 \\
\hline
\end{tabular}

the publication of the first articles.This is a great breakthrough and the first milestone on our way to a widely accepted international scientific journal. We believe that this listing will lead to an increasing number of article submissions. We hope that our publications will be cited even more frequently, which will lead eventually to our first impact factor in a short time.

Our publication pipeline continues to grow, and the number of international submissions is increasing. So far, we have received 55 submissions from authors outside of Germany. We will continue to invite reviews on new developments and perspectives, and we welcome the submission of research articles. Several clinical trial protocols are in preparation, and we have lists of upcoming standard operating procedures and guidelines to be published within the next 12 months.

The Editorial Board has been a great source of support for establishing NRP, and we will have the first rotation of our Editorial Board in 2021. We will announce Section Editors for key areas in neurology such as neuroimmunology and neurooncology, neurodegeneration and

Table 2 Most cited NRP-articles in 2019 and 2020

\begin{tabular}{|c|c|c|c|c|}
\hline Author & Title & Reference & $\begin{array}{l}\text { Nr. of } \\
\text { citations }\end{array}$ & $\begin{array}{l}\text { Article } \\
\text { type }\end{array}$ \\
\hline $\begin{array}{l}\text { Dziewas } \\
\text { et al. [3] }\end{array}$ & $\begin{array}{l}\text { Safety and clinical } \\
\text { impact of FEES }\end{array}$ & $\begin{array}{l}\text { Neurological } \\
\text { Research and } \\
\text { Practice } 2019 \\
\text { 1:16 }\end{array}$ & 16 & Research \\
\hline $\begin{array}{l}\text { Weber } \\
\text { et al. [4] }\end{array}$ & $\begin{array}{l}\text { Distribution and } \\
\text { evolution of acute } \\
\text { interventional } \\
\text { ischemic stroke } \\
\text { treatment in Germany } \\
\text { from } 2010 \text { to } 2016\end{array}$ & $\begin{array}{l}\text { Neurological } \\
\text { Research and } \\
\text { Practice } 2019 \\
\text { 1:4 }\end{array}$ & 21 & Research \\
\hline $\begin{array}{l}\text { Mokli et al. } \\
\text { [5] }\end{array}$ & $\begin{array}{l}\text { Computer-aided } \\
\text { imaging analysis in } \\
\text { acute ischemic stroke } \\
\text { - background and } \\
\text { clinical applications }\end{array}$ & $\begin{array}{l}\text { Neurological } \\
\text { Research and } \\
\text { Practice } \mathbf{2 0 1 9} \\
\text { 1:23 }\end{array}$ & 7 & Review \\
\hline $\begin{array}{l}\text { Göttle et al. } \\
\text { [6] }\end{array}$ & $\begin{array}{l}\text { An unmet clinical } \\
\text { need: roads to } \\
\text { remyelination in MS }\end{array}$ & $\begin{array}{l}\text { Neurological } \\
\text { Research and } \\
\text { Practice } \mathbf{2 0 1 9} \\
\text { 1:21 }\end{array}$ & 5 & Review \\
\hline $\begin{array}{l}\text { Lampe } \\
\text { et al. [7] }\end{array}$ & $\begin{array}{l}\text { Guillain-Barré } \\
\text { syndrome and } \\
\text { SARS-CoV-2 }\end{array}$ & $\begin{array}{l}\text { Neurological } \\
\text { Research and } \\
\text { Practice } 2020 \\
2.19\end{array}$ & 5 & Letter \\
\hline
\end{tabular}

movement disorders, stroke, interventional neurology and critical care, pediatric neurology, cognitive neurology, and functional imaging, and neuromuscular disorders.

As the founding editor of NRP I am grateful for the ever increasing support by the leadership of the German Neurological Society represented by our current President Professor Christine Klein, Past President Professor Gereon Fink, Incoming President Christian Gerloff, the Secretary Professor Peter Berlit, and the Chief Administrative Officer Dr. Thomas Thiekötter. I express my gratitude to our partners at the publisher's office, namely Emily Jones and Cecille Calusa for their continuous support, to all members of the Editorial Board, to the authors for submitting their articles, and to the reviewers for their most important contributions. They all make the first years of NRP so successful.

Please continue to support us to make NRP a well-received and influential voice of German neurology publishing content with international relevance.

Table 3 Most accessed NRP-articles in 2019 and 2020

\begin{tabular}{|c|c|c|c|c|}
\hline Author & Title & Reference & $\begin{array}{l}\mathrm{Nr} \text {.of } \\
\text { accesses }\end{array}$ & $\begin{array}{l}\text { Article } \\
\text { type }\end{array}$ \\
\hline $\begin{array}{l}\text { Sembill } \\
\text { et al. [8] }\end{array}$ & $\begin{array}{l}\text { Resumption of oral } \\
\text { anticoagulation after } \\
\text { spontaneous } \\
\text { intracerebral } \\
\text { hemorrhage }\end{array}$ & $\begin{array}{l}\text { Neurological } \\
\text { Research and } \\
\text { Practice } \mathbf{2 0 1 9} \\
\text { 1:12 }\end{array}$ & 9815 & Review \\
\hline $\begin{array}{l}\text { Berlit et al. } \\
{[9]}\end{array}$ & $\begin{array}{l}\text { "Neurological } \\
\text { manifestations of } \\
\text { COVID-19" - guideline } \\
\text { of the German society } \\
\text { of neurology }\end{array}$ & $\begin{array}{l}\text { Neurological } \\
\text { Research and } \\
\text { Practice } \mathbf{2 0 2 0} \\
\text { 2:51 }\end{array}$ & 6955 & Guideline \\
\hline $\begin{array}{l}\text { Busetto } \\
\text { et al. [10] }\end{array}$ & $\begin{array}{l}\text { How to use and assess } \\
\text { qualitative research } \\
\text { methods }\end{array}$ & $\begin{array}{l}\text { Neurological } \\
\text { Research and } \\
\text { Practice } \mathbf{2 0 2 0} \\
\text { 2:14 }\end{array}$ & 5010 & Review \\
\hline $\begin{array}{l}\text { Gövert } \\
\text { et al. [11] }\end{array}$ & $\begin{array}{l}\text { Antibody-related } \\
\text { movement disorders - } \\
\text { a comprehensive } \\
\text { review of phenotype- } \\
\text { autoantibody correla } \\
\text { tions and a guide to } \\
\text { testing }\end{array}$ & $\begin{array}{l}\text { Neurological } \\
\text { Research and } \\
\text { Practice } \mathbf{2 0 2 0} \\
2: 6\end{array}$ & 4359 & Review \\
\hline $\begin{array}{l}\text { Dziewas } \\
\text { et al. [3] }\end{array}$ & $\begin{array}{l}\text { Safety and clinical } \\
\text { impact of FEES }\end{array}$ & $\begin{array}{l}\text { Neurological } \\
\text { Research and } \\
\text { Practice } 2019 \\
\text { 1:16 }\end{array}$ & 4186 & Research \\
\hline
\end{tabular}




\section{Author's contributions}

WH wrote the manuscript. The author read and approved the final manuscript.

\section{Competing interests}

WH declares he is Editor-in-Chief of Neurological Research and Practice. WH reports payments by the German Neurological Society as compensation for editorial work and travel reimbursement. There are no further competing interests.

\section{Published online: 13 January 2021}

\section{References}

1. Hacke, W. (2019). Announcing the new launch of Neurological Research and Practice. Neurological Research and Practice, 1,7.

2. Hacke, W. (2020). Neurological research and practice: the first year. Neurological Research and Practice, 2, 5.

3. Dziewas, R., auf dem Brinke, M., Birkmann, U., et al. (2019). Safety and clinical impact of FEES - results of the FEES-registry. Neurological Research and Practice, 1, 16

4. Weber, R., Eyding, J., Kitzrow, M., et al. (2019). Distribution and evolution of acute interventional ischemic stroke treatment in Germany from 2010 to 2016. Neurological Research and Practice, 1, 4

5. Mokli, Y., Pfaff, J., dos Santos, D. P., et al. (2019). Computer-aided imaging analysis in acute ischemic stroke - background and clinical applications. Neurological Research and Practice, 1, 23.

6. Göttle, P., Förster, M., Weyers, V., et al. (2019). An unmet clinical need: roads to remyelination in MS. Neurological Research and Practice, 1, 21.

7. Lampe, A., Winschel, A., Lang, C., et al. (2020). Guillain-Barré syndrome and SARS-CoV-2. Neurological Research and Practice, 2, 19.

8. Sembill, J. A., Kuramatsu, J. B., Schwab, S., et al. (2019). Resumption of oral anticoagulation after spontaneous intracerebral hemorrhage. Neurological Research and Practice, 1, 12

9. Berlit, P., Bösel, J., Gahn, G., et al. (2020). "Neurological manifestations of COVID-19" - guideline of the German society of neurology. Neurological Research and Practice, 2, 51 .

10. Busetto, L., Wick, W., \& Gumbinger, C. (2020). How to use and assess qualitative research methods. Neurological Research and Practice, 2, 14.

11. Gövert, F., Leypoldt, F., Junker, R., et al. (2020). Antibody-related movement disorders - a comprehensive review of phenotype-autoantibody correlations and a guide to testing. Neurological Research and Practice, 2, 6 .

\section{Publisher's Note}

Springer Nature remains neutral with regard to jurisdictional claims in published maps and institutional affiliations.

Ready to submit your research? Choose BMC and benefit from:

- fast, convenient online submission

- thorough peer review by experienced researchers in your field

- rapid publication on acceptance

- support for research data, including large and complex data types

- gold Open Access which fosters wider collaboration and increased citations

- maximum visibility for your research: over $100 \mathrm{M}$ website views per year

At $\mathrm{BMC}$, research is always in progress.

Learn more biomedcentral.com/submissions 